\title{
Activity and stability of urease enzyme immobilized on Amberlite resin
}

\author{
Jawad Kadhim Jawad AL-SHAMS, Mustafa Abdul Kadhim HUSSEIN*, and Hussein Kadhem AL- \\ HAKEIM
}

Department of Chemistry, College of Science, University of Kufa, Iraq

\begin{abstract}
Immobilization of enzymes is a good field of study to extend the life of enzyme and reduce the cost of the chemical processes, such as separation processes. Urease is an important enzyme with medical and industrial applications. The aim of the present study is to prepare an immobilized urease on a strong cation exchange resin (Amberlite IR120 Na) and study its activity and stability. We monitored the release of $\mathrm{Na}$ ions in the collected fractions and searching for enzyme in the fractions as indicators of immobilization by ion exchange phenomenon. Sodium is determined by using atomic absorption spectroscopy technique, while the enzyme concentration was tested by Bradford's method. Immobilized urease activity was evaluated by salicylate-hypochlorite method. The results indicated a complete immobilization of urease enzyme on the resin surface with reserving $92 \%$ of the activity of free enzyme. The immobilized urease enzyme on resin showed good stability and it has a $62 \%$ of its activity after 154 days of storage at room temperature. It is concluded that a new immobilized urease enzyme system is prepared with good enzyme activity and stability.
\end{abstract}

Keywords: Amberlite IR120 Na resin, urease, enzyme immobilization.

\section{Introduction}

Immobilization of enzymes on different surfaces is an important method to increase the life and stability of the enzymes and to decrease the cost of the enzyme reactions [1]. Urease (EC 3.5.1.5) is an enzyme that convert urea to $\mathrm{CO}_{2}$ and ammonia [2]. Immobilized urease on various materials have many classic applications [3-6]. Furthermore, some new applications of urease immobilization are introduced including hemodialysis membranes [7], enzymatic bioelectrochemical devices [8], biosensor for the quantitative determination of urea $[9,10]$, and study of protein-surface interaction [11]. The enzyme may be immobilized in several ways such as adsorption on a surface where the enzyme is bound to an inactive substance [7] or by ion exchanging [8], but some immobilization processes can reduce the enzyme activity [12] or change the urease structure (e.g. when immobilization occurred on the nanoceria surface) [13]. Specific protein (prolactin) was found to be adsorbed on the active surfaces with various findings and interactions including changes in the activity [14], secondary or tertiary structure [15], or stability [16].

Previously, we had succeeded in the immobilization of urease enzyme on anionic exchange resin with good stability and activity [17].

This work aims to identify the ability of urease enzyme to be active when it immobilized on a strong cation exchange resin (Amberlite IR120 Na) and study the stability of enzyme-resin system.

\section{Experimental}

\subsection{Materials}

Amberlite IR120 Na resin was supplied from Rohm and Haas Inc. USA. Coomassie Brilliant Blue Fast Staining Solution was supplied by Cusabio Biotech ${ }^{\circledR}$, China. Type III powder $(15,000-50,000$ units/gram solid) of urease (EC3.5.1.5, from Canavalia ensiformis) with a molecular weight of $480,000 \mathrm{Da}$ was obtained from Sigma-Aldrich $^{\circledR}$. Urea solution $(20 \mathrm{mM}$ urea in $2 \mathrm{mM}$ $\mathrm{CaCl}_{2}$ ), Reagent A (62 mM of sodium salicylate, 3.4 $\mathrm{mM}$ sodium nitroprusside, and phosphate buffer $20 \mathrm{mM}$ $-\mathrm{pH}=6.9$ ) and Reagent $\mathrm{B}$ (sodium hypochlorite $7 \mathrm{mM}$ and sodium hydroxide $150 \mathrm{mM}$ ) were supplied by Spinreact $^{\circledR}$, Spain. Hydrochloric acid $37 \%$ was supplied by Mana Scientific Products, India. Phosphate buffer solution $(1.0 \mathrm{M}), \mathrm{pH}=7.4$, was supplied by Reagene Biosciences Private Ltd, India.

\subsection{Preparation of immobilized enzyme on cation exchange resin}

$2 \mathrm{~g}$ of Amberlite IR120 Na resin were suspended in 25 $\mathrm{ml}$ of distilled water, put in a glass chromatography column after swelling in $75 \mathrm{ml}$ of distilled water and regenerated by $1 \mathrm{M} \mathrm{HCl}$. After 2 hours, it was carefully washed with distilled water until neutralization. The urease enzyme $(0.8 \mathrm{mg}$ enzyme in $0.2 \mathrm{ml}$ of phosphate buffer, $\mathrm{pH}=7.4$ ) was added to the top of the column. The mixture was kept for $45 \mathrm{~min}$ at room temperature in order to obtain equilibrium and complete the interaction between the enzyme molecules and the resin.

The fractions (containing urease in phosphate buffer) were collected from the column in $2 \mathrm{ml}$ for each fraction at a flow rate of $1 \mathrm{ml} / \mathrm{min}$. The concentration of $\mathrm{Na}^{+}, \mathrm{H}^{+}$ and urease was measured in each fraction. These ions are the exchangeable cations from the surface of the

\footnotetext{
* Corresponding author. E-mail address: mustafa.rabeea@uokufa.edu.iq (Mustafa Abdul Kadhim Hussein)
} 
resin. If they appeared in the eluent, it means replacement of these cations with the urease molecules.

\subsection{Methods}

Measuring of urease concentration in fractions. The Bradford method for proteins [18] was used for estimation of amount of urease in solution and the difference between quantities before and after immobilization is equal to the quantity of immobilized enzyme on the cationic resin. For calibration curve we used the albumin as a standard at a concentration ranged from 5 to $100 \mu \mathrm{g}$ in $100 \mu \mathrm{l}$. The protein solutions were added onto $5 \mathrm{ml}$ of Coomassie Brilliant Blue dye solution and the mixtures were kept for $5 \mathrm{~min}$ at room temperature. The absorbance was measured at $595 \mathrm{~nm}$ [18]. Absence of protein in the collected fractions indicated the immobilization of urease enzyme.

Assay of urease activity. In order to see if the enzyme is still active after immobilization, we measure the urease activity after adding urea as substrate and measuring the ammonia released from the hydrolysis of urea by the action of urease. Briefly, $2 \mathrm{ml}$ of urea solution $(20 \mathrm{mM}$ urea in $2 \mathrm{mM} \mathrm{CaCl}_{2}$ ) as an enzyme substrate was added on the top of the exchanger and kept for $30 \mathrm{~min}$ at room temperature. The immobilized urease will hydrolyze urea into ammonia and $\mathrm{CO}_{2}$. Then we collect these fractions that contain ammonia $(1 \mathrm{ml})$ and added $1 \mathrm{ml}$ of "Reagent A". The resulted solutions were kept for 10 minutes. Then, the solutions were mixed thoroughly with $1 \mathrm{ml}$ of "Reagent B" and maintained for $10 \mathrm{~min}$ at room temperature [19]. Ammonium ions will react with salicylate in the presence of sodium hypochlorite to produce indophenol, which absorb light at $600 \mathrm{~nm}$. The absorbance of the produced green color measured spectrophotometrically is proportional to the concentration of ammonium ions released from the hydrolysis of urea by urease [19]. The urease activity assay was also repeated on free urease enzyme to compare the activity between free and immobilized enzyme.

Determination of sodium by atomic absorption spectroscopy. Sodium concentration in solution was determined by atomic absorption spectrometry [20] after constructing a calibration curve from six known sodium solutions from 0.01 to $1.0 \mathrm{mg} / \mathrm{L}$. The blank was double deionized water to set the digital display to zero.

Stability of the immobilized urease. The activity of immobilized urease was measured weekly to estimate the stability of the complex as cited in the previous paragraph.

\section{Results and discussion}

The results of the immobilization process, as estimated by Bradford's test method, indicated lack of urease in the collected fraction after addition of urease to the resin column. These results revealed a complete immobilization of urease on the resin (negative test). Furthermore, the decrease of $\mathrm{pH}$ (measured by $\mathrm{pH}$ meter) on the collected fractions indicated occurrence of ion exchange between urease molecules and the hydrogen ions from the surface of resin. The addition of distilled water to the resin-urease mixture leads to evacuation of acidic solution until it became neutral. These results refer to a strong interaction between the resin and protein. Furthermore, sodium ions were also released from the exchange process. Figure 1 showed the release of sodium ion after adding the urease solution on the resin as a result of another ion exchange with the urease molecules.

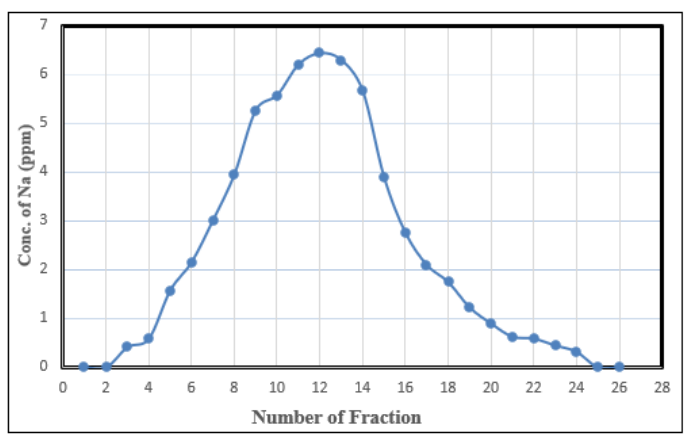

Figure 1. The concentration of sodium released in the collected fractions after exchange with the urease enzyme on the surface of Amberlite.

The urease action on the urea was determined by salicylate-hypochlorite method [19] and showed the ability of immobilized urease to hydrolyze urea. Figure 2 showed the concentration of ammonia produced by the action of immobilized urease on urea substrate.

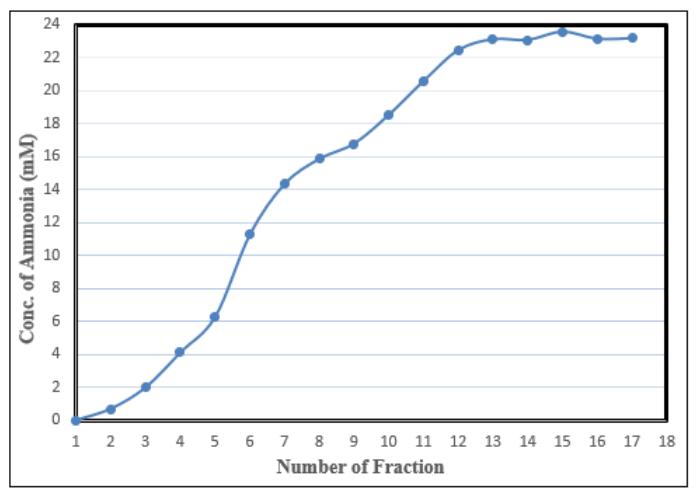

Figure 2. Ammonia concentrations in the fractions collected after adding urea solution to the immobilized urease enzyme on the Amberlite resin.

This result indicated an interaction between the resin and urease by sites far away from the active site and the immobilization reserves the enzyme active site intact. The ability of urease to be immobilized with reserving its activity was seen previously with different stationary phases [2, 4, 5, 17]. Furthermore, in a separate experiment on free urease, the activity of immobilized enzyme is about $92 \%$ of the activity of the free enzyme. This reduction in activity can be explained by the generation of hydrogen ions leading to slight increase in acidity that may affecting the activity of urease. Previous work showed $87 \%$ activity of the free enzyme after immobilization of urease on the Dowex resin (strong anion exchanger) [17]. These results indicated a different behavior of the urease on different surfaces according to the charges on the surface of resin.

Even though the immobilized enzyme has lower catalytic activity comparing with free enzyme, it has 
more stability, reusability, and low cost effective [21, 22]. This result indicated an interaction between the resin and the sites beyond the active site of the enzyme. Hence, the activity is not affected dramatically due lack of involvement of the active sites in the exchange process. The slight change in activity is due to the change in spatial configuration and the orientation of groups beyond the active site. In another study, for comparison, urease covalent immobilization on the template of polysiloxane was reported to be less efficient due to the lack of the enzyme activity [23]. It is found that sloping immobilized urease presents higher temperature resistance, higher similarity to the substrate, and higher constancy of operation [24].

In some previous works [25], the immobilization of urease enzyme needed a chemical cross-linking using formaldehyde, glutaraldehyde and chromium (III) acetate while in the present work, there is no need for this treatment and the urease still binds to the resin tightly. Our study is safer as chromium ion is toxic and some important application of immobilized urease is for reducing urea levels in uremia patients [26].

Many factors affect the activity of protein adsorbed on any surface. It is found previously that high ionic strength produces huge interaction between protein and the adsorbing surface [27]. The activity of immobilized urease on strong cation exchange resin in hydrogen form showed good stability but release of $\mathrm{H}^{+}$during exchange increased the acidity which may cause a decrease in the stability of adsorbed urease.

The results of immobilized enzyme activity expressed as ammonia concentrations with time are presented in Figure 3.

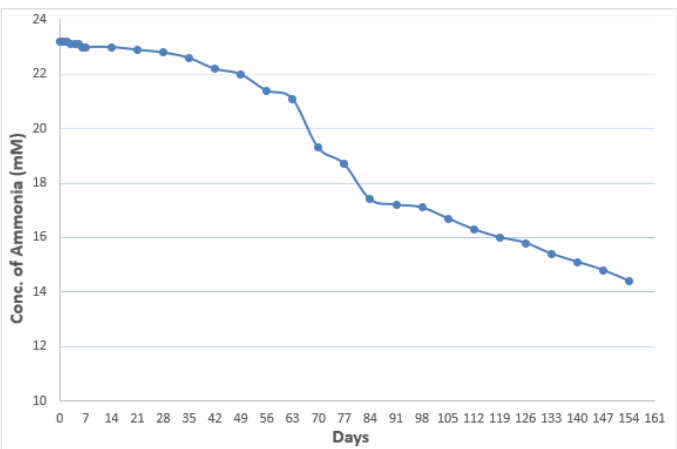

Figure 3. Variation of ammonia concentration, as a measure of immobilized urease activity, with time of storage.

The immobilization of urease on the Amberlite IR120 Na resin is easy, and the enzyme still active with good stability even after 154 days of keeping in distilled water. The enzyme has $62.07 \%$ of its activity after 154 days of preservation in the sterile condition to keep it free from contamination with foreign organisms. In our previous study, the immobilized urease on Dowex ${ }^{\circledR}$ resin showed good stability and slight change noticed in its activity after 15 days of storage at room temperature. However, this study did not monitor the activity of immobilized enzyme for a longer time as done in our study. The thermal stability of the immobilized urease [28] was higher than free enzymes in terms of the $\mathrm{pH}$ and the stop action of some metal ions or organic substances. The stability over time of the immobilized urease is high, its enzymatic activity was stable at $85 \%$ of the first value three months after synthesis [28].

\section{Conclusions}

A new system of immobilized urease enzyme on the strong cation exchange resin in sodium form (Amberlite IR120 Na) is prepared with good enzyme activity (92\% of free enzyme activity) and stability up to 154 days. This new system can be used efficiently to hydrolysis urea in various medical and industrial applications.

\section{Conflict of interest}

The authors declared no conflict of interest.

\section{References}

[1]. R.P. Pogorilyi, I.V. Melnyk, Y.L. Zub, G.A. Seisenbaeva, V.G. Kessler, Enzyme immobilization on a nanoadsorbent for improved stability against heavy metal poisoning, Colloids Surf. B 144 (2016) 135-142.

[2]. G. Pozniak, B. Krajewska, W. Trochimczuk, Urease immobilized on modified polysulphone membrane: Preparation and properties, Biomaterials 16 (1995) 129-134.

[3]. A.K. De Brito, C.S. Nordi, L. Caseli, Algal polysaccharides as matrices for the immobilization of urease in lipid ultrathin films studied with tensiometry and vibrational spectroscopy: Physical-chemical properties and implications in the enzyme activity, Colloids Surf. B 135 (2015) 639-645.

[4]. Y. I. Doğaç, I. Deveci, M. Teke, B. Mercimek, $\mathrm{TiO}_{2}$ beads and $\mathrm{TiO}_{2}$-chitosan beads for urease immobilization, Mater. Sci. Eng. C 42 (2014) 429435.

[5]. F.S. Alatawi, M. Monier, N.H. Elsayed, Amino functionalization of carboxymethyl cellulose for efficient immobilization of urease, Int. J. Biol. Macromol. 114 (2018) 1018-1025.

[6]. S.H. Baysal, R. Karagöz, Preparation and characterization of kappa-carrageenan immobilized urease, Prep. Biochem. Biotechnol. 35 (2005) 135-143.

[7]. F.Y. Mahlicli, S.A. Altinkaya, The effects of urease immobilization on the transport characteristics and protein adsorption capacity of cellulose acetate based hemodialysis membranes, J. Mater. Sci. Mater. Med. 20 (2009) 2167-2179.

[8]. D.E. Anderson, S. Balapangu, H.N. Fleischer, R. Viade, F. Krampa, P. Kanyong, G. Awandare, E. Tiburu, Investigating the influence of temperature on the kaolinite-base synthesis of zeolite and urease immobilization for the potential fabrication of electrochemical urea biosensors, Sensors (Basel) 17 (2017) 1831.

[9]. A. Tiwari, S. Aryal, S. Pilla, S. Gong, An amperometric urea biosensor based on covalently immobilized urease on an electrode made of hyperbranched polyester functionalized gold nanoparticles, Talanta 78 (2009) 1401-1407. 
[10]. E. György, F. Sima, I. Mihailescu, T. Smausz, G. Megyeri, R. Kékesi, B. Hopp, L. Zdrentu, S. Petrescu, Immobilization of urease by laser techniques: synthesis and application to urea biosensors, J. Biomed. Mater. Res. A 89 (2009) 186-191.

[11]. N. Mohamad, N. Marzuki, N. Buang, F. Huyop, R. Wahab, An overview of technologies for immobilization of enzymes and surface analysis techniques for immobilized enzymes, Biotechnol. Biotechnol. Equip. 29 (2015) 205-220.

[12]. L. Zhang, Y. Du, J. Song, H. Qi, Biocompatible magnetic nanoparticles grafted by poly(carboxybetaine acrylamide) for enzyme immobilization, Int. J. Biol. Macromol. 118 (2018) 1004-1012.

[13]. H.K. Al-Hakeim, M. K. Kadhem, E.A. Grulke, Immobilization of urease enzyme on nanoceria modifies secondary and tertiary protein structures, Acta Chimica Slovaka 9 (2016) 44-53.

[14]. H.K. Al-Hakeim, I.M. Al-Dahan. R. Bustan, Interaction of prolactin hormone with the surfaces of two new azo compounds, Int. J. Pharm. Pharm. Sci. 6 (2014) 383-387.

[15]. H.K. Al-Hakeim, R.S. Al-Zabeba, E.A. Grulke, E.A. Al-Mulla, Interaction of calcium phosphate nanoparticles with human chorionic gonadotropin modifies secondary and tertiary protein structure, Nova Biotechnol. Chim. 14 (2015) 141-157.

[16]. H.K. Al-Hakeim, K. Jasem, S. Moustafa, Antipepsin activity of silicon dioxide nanoparticles, Rev. Colomb. Quim. 45 (2016) 5-11.

[17]. H.K. Al-Hakeim, J.K. Al-Shams, M.A. Kadhem, Immobilization of urease enzyme on ion-exchange resin, J. Univ. Babylon 20 (2012) 1231-1236.

[18]. M.M. Bradford, A rapid and sensitive for the quantitation of microgram quantities of protein utilizing the principle of protein-dye binding, Anal. Biochem. 72 (1976) 248-254.

[19]. C.E. Bower, T. Holm-Hansen, A salicylatehypochlorite method for determining ammonia in seawater, Can. Fish Aquat. Sci. 37 (1980) 794-798.
[20]. M.J. Fishman, S.C. Downs, Methods for analysis of selected metals in water by atomic absorption, U.S. Geological Survey Water-Supply Paper 1540C (1966) 38-41.

[21]. C. Vaghela, M. Kulkarni, S. Haram, R. Aiyer, M. Karve, A novel inhibition based biosensor using urease nanoconjugate entrapped biocomposite membrane for potentiometric glyphosate detection, Int. J. Biol. Macromol. 108 (2018) 3240.

[22]. S.F. D'Souza, J. Kumar, S.K. Jha, B.S. Kubal, Immobilization of the urease on eggshell membrane and its application in biosensor, Mater. Sci. Eng. C 33 (2013) 850-854.

[23]. R.P. Pogorilyı̆, V.P. Goncharik, L.I. Kozhara, I. Zub, Covalent immobilization of urease on polysiloxane templates containing 3-aminopropyl and 3-mercaptopropyl groups, Prikl. Biokhim. Mikrobiol. 44 (2008) 621-625.

[24]. J. Zhou, S. Chen, J. Wang, Research on the orientedly immobilized urease via concanavalin A, Chinese J. Biotechnol. 24 (2008) 617-621.

[25]. S. Sungur, M. Elcin, U. Akbulut, Studies on immobilization of urease in gelatin by crosslinking, Biomaterials 13 (1992) 795-800.

[26]. M.V. Cattaneo, T.M. Chang, The potential of a microencapsulated urease-zeolite oral sorbent for the removal of urea in uremia, ASAIO Trans 37 (1991) 80-87.

[27]. H.K. Al-Hakeim, K. Jasem, High ionic strength enhances the anti-pepsin activity of titanium dioxide nanoparticles, Nano Biomed. Eng. 8 (2016) 136-143.

[28]. S. Dumitriu, M. Popa, V. Artenie, F. Dan, Bioactive polymers. 56: Urease immobilization on carboxymethylcellulose, Biotechnol. Bioeng. 34 (1989) 283-290.

Received: 10.07.2019

Received in revised form: 16.01.2020

Accepted: 18.01.2020 